\title{
FAKTOR PENENTU SETTING FISIK DALAM BERAKTIFITAS DI KORIDOR JALAN SEBAGAI RUANG PUBLIK Studi Kasus Kampung Kauman Desa Pakuncen Kabupaten Nganjuk
}

\author{
Erisa Ardiansari ${ }^{1}$, Jenny Ernawati ${ }^{2}$, Agung Murti Nugroho ${ }^{3}$ \\ ${ }^{1}$ Mahasiswa S2 Arsitektur Lingkungan Binaan, Universitas Brawijaya Malang. \\ ${ }^{2}$ Pengajar Program Magister Arsitektur Lingkungan Binaan, Universitas Brawijaya. \\ ${ }^{3}$ Pengajar Program Magister Arsitektur Lingkungan Binaan, Universitas Brawijaya. \\ E-mail: shasya83@gmail.com; jny23ern@gmail.com; sasimurti@yahoo.co.id
}

\begin{abstract}
ABSTRAK
Perkembangan sebuah kampung menjadi berkurang seiring dengan terkikisnya nilai-nilai budaya dan tradisi leluhur. Dalam peruntukan sebuah kampung yang pertama kali menjadi sorotan adalah koridor jalannya, menjadi menarik apabila dalam koridor tersebeu terdapat berbagai aktifitas yang menjadi center point suatu desa ataupun kampung. Penelitian ini mengambil studi di Desa Pakuncen Kabupaten Nganjuk. Dimana di desa tersebut terdapat koridor jalan yang cukup menarik, karena terdapat bangunan bersejarah yang menjadi tolak ukur kemunculan desa tersebut. Untuk itu diperlukan penataan setting fisik koridor agar dapat memenuhi kebutuhannya sebagai ruang publik yang dapat mewadahi aktifitas yang terjadi pada bangunan-bangunan di area koridor tersebut. Landasan teori yang digunakan pada penelitian ini adalah teori mengenai behavior setting dengan metode deskriptif kualitatif. Dengan metode place centered maps dan person centered maps dapat diperoleh hasil berupa penataan setting fisik koridor jalan yang berpengaruh pada aktifitas sehari-hari yang terjadi.
\end{abstract}

Kata Kunci : Koridor jalan, ruang publik, aktifitas dan perilaku

\section{ABSTRACT}

The development of a village to be reduced along with the erosion of cultural values and traditions of their ancestors. In the allotment of a village for the first time in the spotlight is the hall way, be interesting if the tersebeu corridor there are various activities that becomes the center point of a village or town. This study took a study in the Village Pakuncen Nganjuk. Where in the village there is a road corridor is quite interesting, because there is a historic building that became a benchmark for the appearance of the village. It is necessary for the arrangement of the physical setting of the corridor in order to meet their needs as a public space that can accommodate activities that occur in buildings in the corridor area. The cornerstone of the theory used in this research is the theory of the behavior setting with descriptive qualitative method. With the method centered place and person-centered maps maps can be obtained results form the physical arrangement of the road corridor settings that affect day-to-day activities that occur.

Keywords : Road corridors, public spaces, activities and behavior 


\section{Pendahuluan}

Seiring berjalannya waktu menyebabkan terkikisnya budaya ataupun ritual tradisional yang ditandai oleh minimnya kampung-kampung dikawasan perkotaan maupun pedesaan. Kebersaamaan menjadi ciri atau identitas adanya kampung yang merupakan identitas sosial yang terjalin didalamnya.

Kampung, bukanlah sekedar kumpulan bangunan, tetapi lahan yang sangat kaya untuk menggali ilmu yang dikandung jauh di dalam pertiwi budaya nusantara. Ilmu yang sesuai dengan fitrah manusia, masyarakat, dan alam nusantara.

Pusat aktifitas yang sering dilalui masyarakat antara lain adalah koridor jalan, dimana segala aktifitas bersama dilakukan disini. Dapat dikatakan bahwa koridor jalan kampung berfungsi sebagai ruang publik yang mewadahi berbagai kegiatan bersama maupun kolektif. Karena disini terdapat pula area publik yang sakral maka bisa dimanfaatkan untuk kegiatan ritual bersama-sama.

Hubungan antara ruang publik dan ruang pribadi di koridor jalan terjadi dengan cukup menarik dan patut ditelaah lebih lanjut. Penggunaan ruang publik membentuk teritori tertentu yang memisahkan dengan ruang privat, demikian sebaliknya. Setiap perilaku manusia seperti mengolah unsur fisik atau hanya membatasi ruangan yang mereka gunakan di ruangan publik merupakan salah satu bukti pemanfaatan ruang publik.

Pola pemanfaatan koridor jalan sebagai ruang bersama diharapkan dapat diarahkan menjadi wadah kebersamaan antar masyarakat yang terjalin lebih erat. Terbentuknya ritual ataupun aktifitas sosial juga berasal dari ruang publik. Sehingga perlu ditelaah juga korelasi ruang publik yang ada dengan koridor jalan disekitarnya berkaitan dengan aktifitas sosial masyarakatnya.

Desa Pakuncen Kota lama Kertosono adalah merupakan salah satu daerah istimewa Kabupaten Nganjuk. Awal terbentuknya Desa Pakuncen adalah ketika salah satu murid kanjeng Sunan Giri dibantu beberapa rekan dan muridnya mendirikan lahan untuk tempat pemukiman. Dan selanjutnya untuk keperluan dakwah maka didirikan masjid yang kemudian diberi nama masjid kauman yang sekarang berganti nama masjid baiturahman.

Bangunan ini kemudian dipergunakan untuk mengajar mengaji dan kegiatankegiatan lainnya yang sifatnya untuk mengembangkan syiar agama Islam. Muridmuridnya berdatangan dari seluruh daerah, sehingga tahun demi tahun semakin ramai dikunjungi. Dan karena penghuni daerah ini semua pemeluk agama islam yang taat dan sebagai pusat pondok pesantren, maka desa baru ini diberi nama desa Kauman.

Pusat kegiatan di koridor terletak pada masjid yang dibangun pada abad ke16 ini terbuat dari kayu (atap dan tiangnya) dan kulit kayu pada dindingnya. Namun seiring berjalannya waktu masjid tersebut mengalami perbaikan, atas prakarsa bapak H. Harmoko (yang pada saat itu masih menjabat sebagai menteri penerangan republik Indonesia). Kemudian dilaksanakan perbaikan atap dan penambahan serambi. Dan akhirnya masjid kauman dikenal dengan masjid baitur rohman.

Sehingga koridor jalan yang paling ramai adalah disekitar pesantren dan masjid tersebut. Adapula makam leluhur yang letaknya bersebelahan dengan masjid dan masih linear di satu koridor. Dengan demikian hal ini menjadi menarik ketika dalam koridor ruang publik terdapat beberapa macam ruang-ruang ataupun 
bangunan yang terdapat aktifitas keagamaan, sosial maupun ritual-ritual yang berdasar kepercayaan leluhur. Semuanya terjadi dalam satu koridor ruang publik.

Ditinjau dari Rencana Pemerintah Daerah Kabupaten Nganjuk terdapat kebijakan untuk mengembangkan sektor religi dan untuk mempertahankan kawasan bersejarah. Dalam hal ini Desa Pakuncen merupakan salah satu cikal bakal tumbuhnya kawasan religi di Kabupaten Nganjuk. Untuk itu perlu dilestarikan serta diperkenalkan sebagai kawasan wisata religi.

\title{
2. Tinjauan Pustaka
}

Ruang personal didefinisikan sebagai :

\begin{abstract}
"An invisible, variable volume of space surrounding on individual which defines that individual's preferred distance fromm others" (Volume ruang yang tidak terlihat dan berubah-ubah disekitar individu yang menentukan jarak yang disukai individu bersangkutan terhadap individu lainnya).

Burgoon dan para pendukung teori ini percaya bahwa manusia memiliki keinginan untuk berdekatan dengan orang lain tetapi pada saat yang bersamaan juga ingin menjaga jarak dengan orang lain. Pada umumnya orang tidak suka hidup menyendiri dan terisolasi, namun ada kalanya orang membutuhkan privasi.
\end{abstract}

Dalam mengembangkan teorinya, Burgoon mendapat masukan dari pendiri teori Prosemik, ahli antropologi Edward Hall yang sebelumnya melakukan penelitian terhadap masyarakat Amerika Utara. Hall (1996) menjelaskan prosemik sebagai jarak di antara orang-orang dalam melakukan transaksi atau tindakan sehari-hari. Prosemik juga membahas mengenai pengaturan ruangan (misalnya di rumah atau di kantor) hingga tata letak (layout) suatu kota. Menurut Hall terdapat empat zona prosemik dan masing-masing digunakan orang untuk berbagai alasan berbeda.

Menurut Hall (1996), cara bagaimana ruangan diatur dan digunakan dalam interaksi merupakan masalah budaya. Perbedaan rasa atau indra (sense) seperti pandangan, penciuman dan sebagainya adalah penting pada berbagai budaya yang berbeda. Di beberapa negara seperti Amerika, indera penglihatan dan pendengaran bersifat penting, sedangkan pada kebudayaan lain sentuhan merupakan hal yang lebih penting. Secara umum, indra apa yang lebih dominan pada suatu budaya akan menentukan cara bagaimana mengatur dan menggunakan ruang.

Budaya juga memiliki definisi berbeda mengenai diri (self) yang mempengaruhi bagaimana ruang didefinisikan dan digunakan. Masyarakat Barat belajar mengenal diri melalui kulit dan pakaian, namun orang Arab meletakkan 'diri' mereka jauh di dalam tubuh mereka.

Hall (1996) menentukan tiga tipe dasar ruang sebagai berikut.

1. Anggota ruang tetap (fixed-feature space) yang terdiri atas benda-benda yang tidak bisa dipindahkan seperti dinding dan kamar.

2. Anggota ruang semi tetap (semifixed-feeature space) yaitu benda-benda yang dapat dipindahkan seperti perabot.

3. Ruang informal (informal space) yaitu wilayah pribadi di sekujur tubuh yang bergerak mengikuti tubuh dan menentukan jarak diantara individu.

Berdasarkan penelitiannya terhadap kebudayaan Anglo-American, Hall (1996) kemudian menyimpulkan adanya empat kategori jarak dalam komunikasi 
yaitu: intim (0-18 inchi), personal (1-4 kaki), sosial (4-12 kaki), dan publik (di atas 12 kaki) dan setiap kategori jarak memiliki aturan perilaku masing-masing.

1. Jarak intim.

Perilaku yang tercakup dalam jarak intim (intimate distance) dengan radius 0-8 inchi ini mulai dari melakukan senntuhan, berbisik hingga mampu meneliti karrakteristik wajah seseorang. Hall (1996) menemukan fakta menarik bahwa seseorang yang berada dalam lingkungan intim namun tidak bersama dengan rekan intimnya (misalnya pacar atau teman dekat) sering kali berupaya menciptakan pengalaman tidak intim. Pengamatannya terhadap para pengguna lift yang berdiri berdekatan dalam jarak intim menunjukkan meraka justru berupaya menciptakan pengalaman tidak intim. Misalnya, mengalihkan pandangan ke berbagai objek non-manusia yang ada di lift. Posisi tangan lurus di samping badan atau memegangi benda yang mereka bawa.

2. Jarak personal.

Perilaku yang tercakup dalam zona personal yang berada dalam radius 18 inchi hingga 4 kaki dimulai dari menyenntuh tangan hingga berbicara dalam jarak yang cukup dekat. Sebagian besar hubungan antarindividu yang bersifat akrab dan hangat terjadi dalam jarak personal ini. Jarak personal biasanya digunakan dalam hubungan seseorang keluarga tau teman. Namun, untuk jarak yang paling jauh (empat kaki) biasanya digunakan dalam komunikaii dengan orang-orang yang kuranng akrab. Hall mengemukakan bahwa dalam jarak personal volume suara biasanya sedang (tidak keras, tetapi juga tidak pelan) dan bahkan menurut Burgoon, pada jarak ini, orang masih dapat merasakan panas tubuh (jika menyentuh) dan bau tubuh lawan bicara.

3. Jarak sosial.

Dalam radius antara 4-12 kaki, jarak sosial biasanya menjadi ciri dari percakapan di masyarakat dan biasanya digunakan dalam hubungan antara teman kerja dilingkungan pekerjaan mereka. Hall menyatakan, jarak sosial yang mendekati 4 kaki biasanya digunakan oleh mereka yang berada dalam suasana kurang normal (casual), misalnya percakapan antara orang-orang yang diundang dalam suatu resepsi. Walaupun jaraknya tampak jauh, namun percakapan yang berlangsung dalam jarak yang mendekati 4 kaki masih mampu menunjukkan tekstur kulit atau rambut lawan bicara dengan cukup jelas. Jarak yang lebih jauh biasanya dihubungan dengan inndividu yang harus berbicara lebih keras daripada mereka dalam jarak yang lebih dekat. Sebagai tambahan, mereka yang berada dalam jarak sosial yang jauh dinilai lebih formal dibandingkan dengan jarak sosial yang dekat. Jarak sosial yang terletak pada bagian yang jauh memungkinkan orang yang melakukan beberapa pekerjaan sekaligus. Misal, petugas resepsionis di kantor yang tetap dapat melakukan pekerjaannya sambil bercakap-cakap dengan tamu yang dating mendekat. Dalam hal ini, dimungkinkan mengawasi orang sambil tetap dapat menyelesaikan pekerjaan.

4. Jarak publik. 
Pada jarak 12 kaki atau lebih jauh merupakan jarak publik. Contoh jarak public yang terdekat adalah komunikasi antara dosen dan mahasiswa di ruang kelas. Jarak publik yang terdekat yang lebih jauh -25 kaki atau lebih- misalnya pidato presiden di gedung parlemen. Karena jaraknya yang jauh, maka raut muka atau reaksi wajah lawan bicara menjadi lebih sulit untuk diamati, kecuali dibantu menggunakan teknologi layar monitor besar. Pantas kesenian, misalnya pertunjukkan drama, yang diadakan di gedung pertunjukan merupakan contoh jarak public yang jauh. Dalam hal ini para pemain harus melebih-lebihkan perilaku, misalnya mengucapkan kata-kata dengan keras agar dapat didengar penonton.

Ketika orang terlibat dalam percakapan, terdapat delapan faktor yang terlibat dalam hal bagaimana mereka menggunakan ruang (Hall 1996), yaitu sebagai berikut.

1. Posture-sex factors: mencakup jenis kelamin peserta percakapan (partisipan) dan posisi tubuh mereka (berdiri, duduk, berbaring)

2. Sociofugal-sociopetal axis: kata 'sociofugal' berarti memperlemah interaksi sedangkan 'sociopetal' berarti memperkuat interaksi. Axis adalah sudut bahu relative terhadap lawan bicara. Mereka yang terlibat dalam percakapan bisa saling berhadapa-hadapan, saling membelakangi atau berada pada posisi lainnya. Beberapa posisi tertentu berhadapan (face-to-face) akan mendorong interaksi, sedangkan posisi lainnya seperti membelakangi akan memperlemah interaksi.

3. Factor Kinesthetic: ini adalah kedekatan para individu dalam hal sentuhan. Para individu berada dalam jarak atau jangkauan yang dapat menimbulkan kontak fisik atau dalam jarak yang dekat.

4. Perilaku menyentuh: para individu melakukan belaian dan genggaman, membuat tekanan, sentuhann dan sebagainya

5. Tanda visual: misalnya melakukan kontak mata

6. Tanda panas: penerimaan panas tubuh dari lawan bicara atau sebaliknya

7. Tanda bau: jenis dan derajat bau yang diterima lawan bicara

8. Kekerasan suara: kekerasam suara dapat mempengaruhi ruang atau jarak antara individu

\section{Metode}

Penelitian ini menggunakan jenis metode penelitian Deskriptif Kualitatif, seperti kita ketahui bahwa metode tersebut dirancang untuk mengumpulkan informasi tentang keadaan-keadaan nyata sekarang (sementara berlangsung). Tujuan utama dalam menggunakan metode ini adalah untuk menggambarkan sifat suatu keadaan yang sementara berjalan pada saat penelitian dilakukan, dan memeriksa sebab-sebab dari suatu gejala tertentu (Travers, 1978)

\section{Hasil Pembahasan}

\subsection{Gambaran Umum Lokasi Studi}

Kabupaten Nganjuk merupakan salah satu Kabupaten di Jawa timur yang memiliki luas wilayah sekitar $\pm 1.224,33$ Ha. Yang terdiri dari 20 Kecamatan. Sebagian masyarakatnya adalah suku Jawa, dan agama mayoritas adalah Islam. 


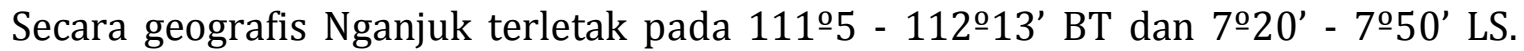
Adapun batas-batas wilayah yaitu :

Sebelah Utara : Kabupaten Bojonegoro

Sebelah Timur : Kabupaten Jombang dan Kediri

Sebelah Selatan $\quad$ : Kabupaten Kediri dan Trenggalek

Sebelah Barat $\quad$ : Kabupaten Ponorogo dan Madiun
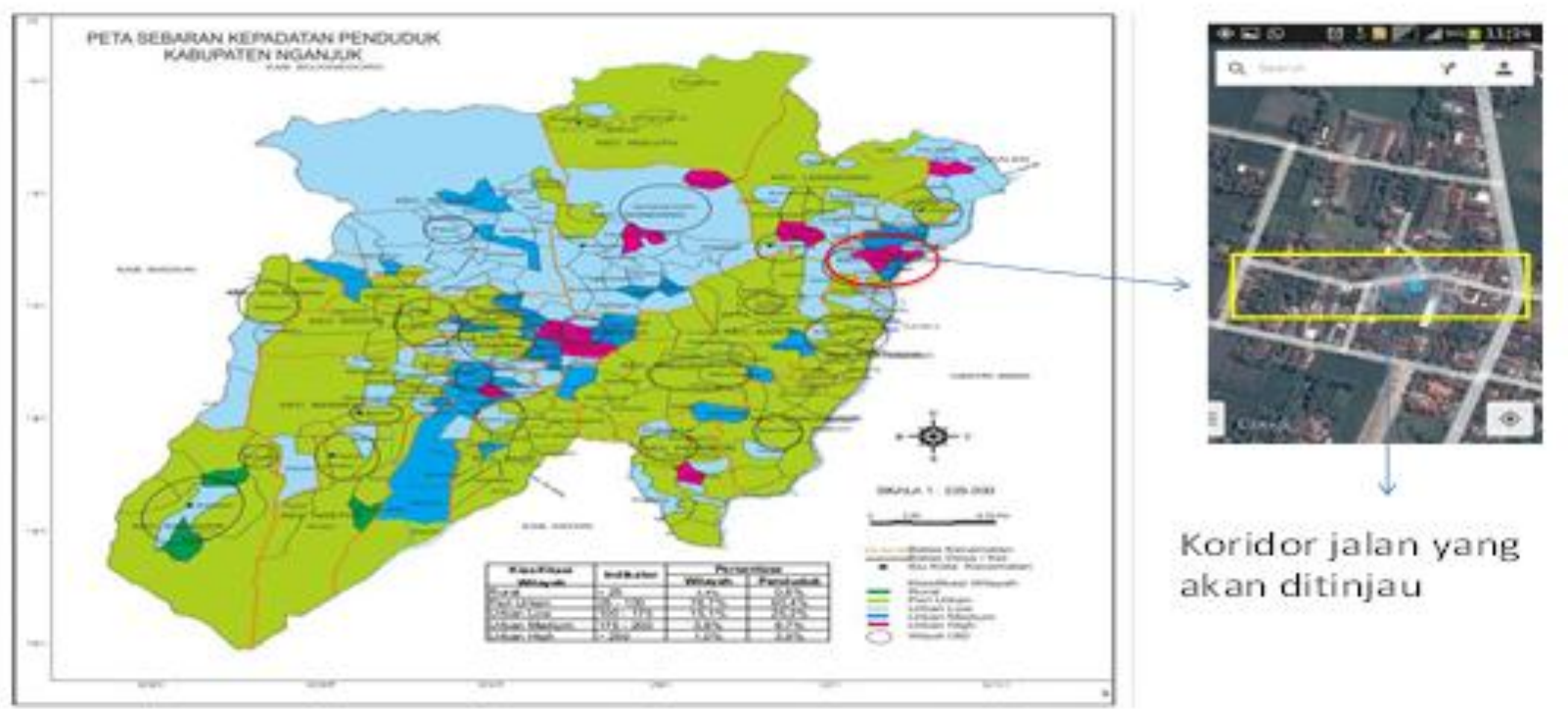

Koridor jalan yang akan ditinjau

Gambar 1. Peta Lokasi yang ditinjau

Desa Pakuncen Kota Lama Kertosono merupakan salah satu Daerah Istimewanya Kabupaten Nganjuk. Secara geografis, desa Pakuncen berada di wilayah kecamatan Patianrowo (sekitar $7 \mathrm{~km}$ arah utara kertosono). Desa ini memiliki luas wilayah $11.075 \mathrm{Ha}$, yang dihuni oleh 65 Kepala Keluarga dengan jumlah penduduk 324 jiwa. Koridor jalan yang diambil adalah titik awal terbentuknya Desa Pakuncen, dimana terdapat bangunan-bangunan bersejarah antara lain masjid dan makam.

\subsection{Analisis dan pembahasan kondisi setting dengan pengguna aktifitas di koridor jalan}

Pada pagi hari aktifitas banyak dilakukan untuk kegiatan belajar mengajar atau pendidikan dan dilakukan sebagian besar oleh anak-anak. Pada siang hari aktifitas masih didominasi oleh anak-anak yang beristirahat maupun pedagang keliling yang menjajakan dagangannya pada saat istirahat sekolah. Sedangkan pada sore hari aktifitas cenderung untuk kegiatan keagamaan dalam hal ini lalu lalang peserta pengajian mendominasi pengguna koridor. Dan malam hari aktifitas mulai sepi hanya beberapa peziarah pada hari-hari tertentu yang menggunakan koridor ini sebagai tempat parkir.

Secara umum analisis pola pemanfaatan dan pola aktifitas pengguna koridor jalan desa pakuncen berdasarkan waktu sehari-hari adalah sebagai berikut : 


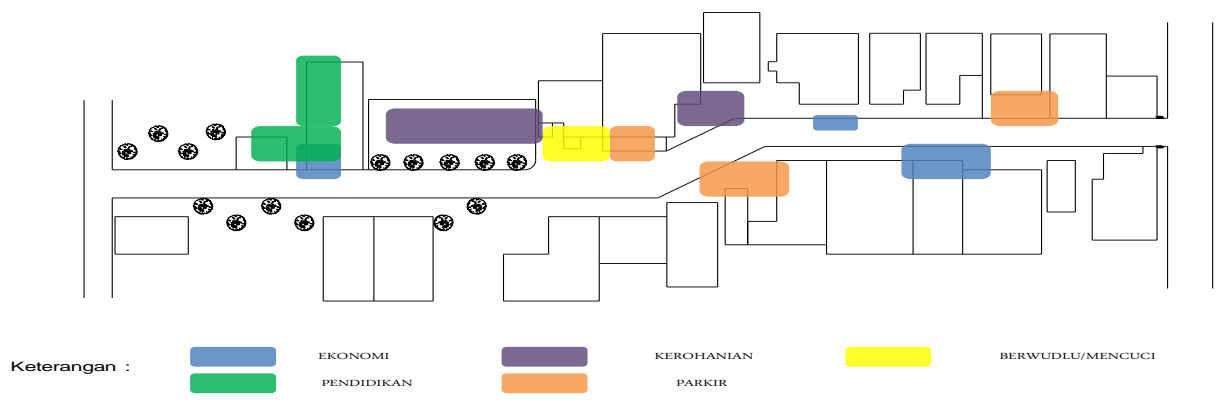

Gambar 2. Place Centered Maps sehari-hari

Untuk hari-hari khusus dalam penelitian ini diambil sample pada saat hari raya idul adha. Karena merupakan hari raya keagaaman Islam dimana mayoritas masyarakatnya beragama Islam.

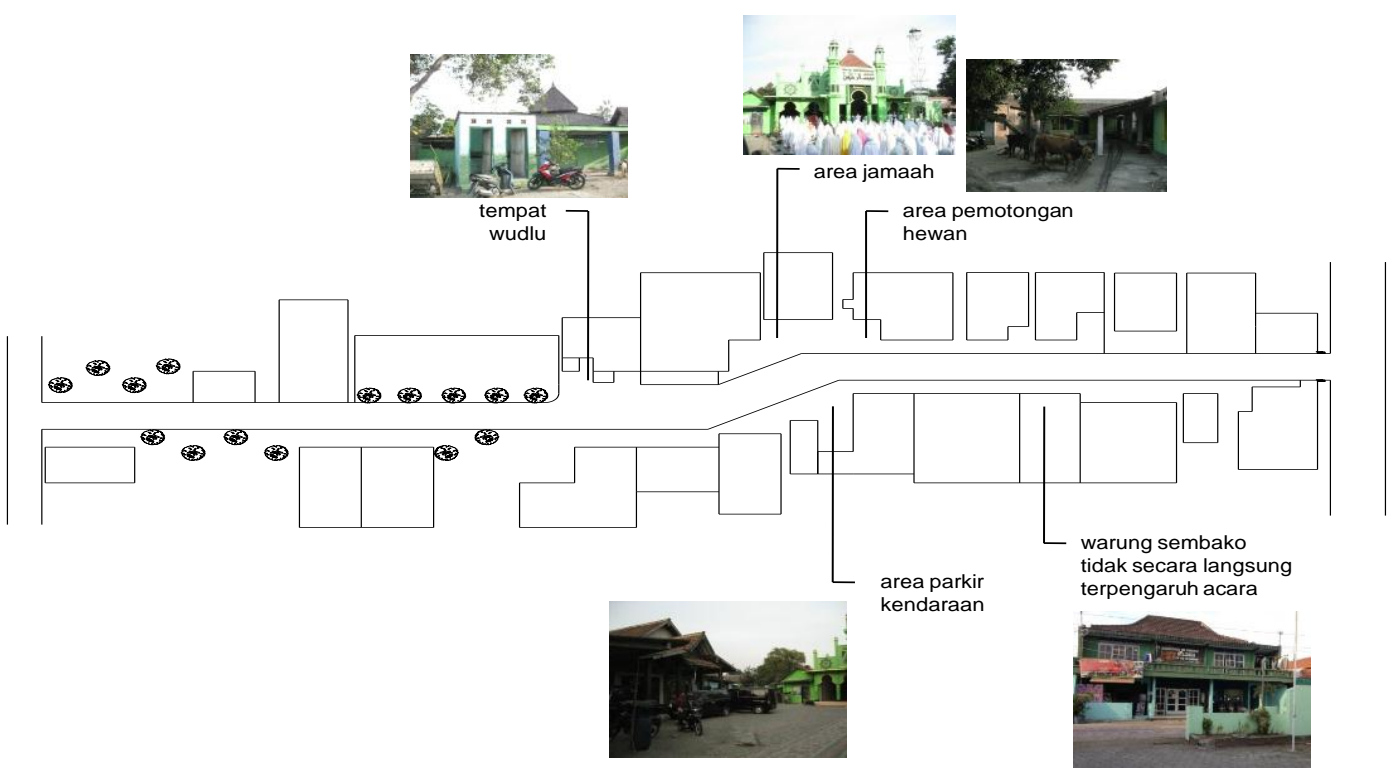

Gambar 3. Place Centered Maps Pada Saat Hari Raya Idul Adha

Tabel berikut merupakan hubungan antara setting fisik kegiatan yang saling mempengaruhi dalam pemanfaatan penggunaan koridor jalan secara umum : 
Tabel 1. Hubungan antara setting fisik dan penggunaan koridor jalan

\begin{tabular}{|c|c|c|c|c|c|c|c|c|c|c|c|}
\hline $\begin{array}{c}\text { HARI } \\
\text { MINGGU }\end{array}$ & $\begin{array}{l}\text { HARI } \\
\text { SABTU }\end{array}$ & $\begin{array}{l}\text { HARI } \\
\text { JUMAT }\end{array}$ & $\begin{array}{l}\text { HARI } \\
\text { KAMIS }\end{array}$ & $\begin{array}{l}\text { HARI } \\
\text { RABU }\end{array}$ & $\begin{array}{c}\text { HARI } \\
\text { SELASA }\end{array}$ & $\begin{array}{l}\text { HARI } \\
\text { SENIN }\end{array}$ & $\begin{array}{c}\text { EKONO } \\
\text { MI }\end{array}$ & $\begin{array}{c}\text { KEROHANI } \\
\text { AN }\end{array}$ & $\begin{array}{l}\text { PENDIDI } \\
\text { KAN }\end{array}$ & PARKIR & $\begin{array}{c}\text { BERWU } \\
\text { DLU / } \\
\text { MENCU } \\
\text { Cl }\end{array}$ \\
\hline SPOT 01 & & & & & & & & v & & & \\
\hline SPOT 02 & & & $\begin{aligned}= & \text { SPOT } \\
& 04\end{aligned}$ & & & $\begin{array}{c}=\text { SPOT } \\
03\end{array}$ & & & & & v \\
\hline SPOT 03 & & & $\begin{array}{c}=\text { SPOT } \\
05\end{array}$ & & & $\begin{array}{c}=\text { SPOT } \\
\\
04\end{array}$ & & & & v & \\
\hline SPOT 04 & & $\begin{array}{c}=\text { SPOT } \\
05\end{array}$ & & $\begin{array}{c}=\text { SPOT } \\
06\end{array}$ & & $\begin{array}{c}=\text { SPOT } \\
05\end{array}$ & & & & v & \\
\hline SPOT 05 & & & & $\begin{array}{c}=\text { SPOT } \\
07\end{array}$ & & $\begin{array}{c}=\text { SPOT } \\
06\end{array}$ & & v & & & \\
\hline SPOT 06 & & & & $\begin{array}{c}=\text { SPOT } \\
08\end{array}$ & & $\begin{array}{c}=\text { SPOT } \\
07\end{array}$ & & & & v & \\
\hline SPOT 07 & & & & $\begin{array}{c}=\text { SPOT } \\
10\end{array}$ & = SPOT 08 & $\begin{array}{c}=\text { SPOT } \\
09\end{array}$ & $v$ & & & & \\
\hline
\end{tabular}

Untuk pemanfaatan koridor jalan kampung sehari-hari, koridor jalan kampung mempunyai pola pemanfaatan tertentu dimana setiap pola pemanfaatan ditandai dengan adanya spot-spot yang menunjukkan batas antara ruang privat dan ruang publik. Dalam setiap spot diketahui mempunyai unsur pembentuk pemanfaatan yang berbeda-beda. Dominasi unsur tersebut diwujudkan dalam beberapa kegiatan antara lain :

1. Kegiatan ekonomi/bisnis

Kegiatan ini didominasi oleh pedagang keliling beraneka makanan, minuman maupun barang, dimana kegiatan ekonomi/bisnis berlangsung dengan singkat yang tercatat dalam place centered maps berjangka beberapa kali secara sporadic dan acak, yaitu kegiatan PKL yang berhenti menunggu pembeli (mangkal).

2. Kegiatan Parkir Kendaraan

Kegiatan ini terbagi menjadi dua kelompok unsur pembentuk pemanfaatan.

Kelompok pertama adalah kelompok dimana pemilik sepeda motor/mobil bukanlah warga di dekat area kendaraan terparkir, seringkali merupakan tamu atau saudara yang sedang berkunjung. Kelompok kedua adalah apabila pemilik kendaraan merupakan warga penghuni rumah dekat area kendaraan terparkir.

3. Kegiatan Berwudhu/Mencuci

Kegiatan kelompok pemanfaatan ini adalah gabungan dari tiga setting unsur pembentuk yang terpaut menjadi satu yaitu setting ruang, setting waktu dan setting sosial.

\section{Kesimpulan}

Pemanfaatan koridor jalan kampung kauman sebagai ruang publik mempunyai pola tertentu sesuai kebiasaan pemanfaatan yang ada. Terdapat dua pola kelompok pemanfaatan sehari-hari dan pola pemanfaatan untuk acara khusus.Pola pelaku pemanfaatan koridor jalan kampung kauman sebagai ruang publik didominasi oleh 
lelaki dewasa. Kegiatan dalam pemanfaatan tersebut merupakan kegiatan ekonomi/bisnis banyak dilakukakan oleh wanita dewasa. Kemudian ruang-ruang yang dimanfaatkan sebagai ruang parkir kendaraan dan kegiatan kerohanian didominasi oleh laki-laki dewasa. Sedangkan anak-anak mendominasi pada saat jam masuk maupun pulang sekolah yaitu pada area pendidikan. Pada beberapa bagian koridor jalan terdapat pergeseran kegiatan yang seharusnya dilakukan di ruang privat namun warga menggunakan ruang publik sebagai tempat kegiatan tersebut. Hal ini tentunya menyebabkan adanya pergeseran fungsi ruang dari yang seharusnya. Koridor jalan kampung kauman menunjukkan bahwa penggunaan suatu ruang tertentu dalam satu setting mengalami suatu proses identifikasi tertentu. Hanya saja identifikasi ersebut tidak berpengaruh pada setting sosial. Setting sosial lebih kepada hubungan baik antar warga. Koridor jalan kampung adalah tempat yang sangat penting untuk kelangsungan hubungan kemasyarakatan. Karena dalam koridor jalan inilah kita dapat bersilaturahmi, parkir, tempat acara, dan tentunya sarana untuk memperoleh rejeki dari segi ekonomi maupun bisnis. Toleransi antar warga juga terbentuk dalam koridor ini, berbagai lapisan masyarakat berkumpul dan saling bertegur sapa. Menambah keakraban satu sama lain. Gotong royong juga terbentuk disini, dengan saling bersama-sama menjaga lingkungan kampung.

\section{Daftar Pustaka}

Altman, l. 1975. The Environment and Social Behavior. Montery, CA: Brooks/Cole. Asriany, S. 2012. Dinamika Ruang Publik Eksklusif dan Inklusif Pada Permukiman Masyarakat Menengah Kebawah, Studi Kasus Permukiman Panakkukang Makassar. Dalam J. Silas, Format-Format Perubahan Ruang (hal. 325-424). Tunggal Sakti.

Carr, S. 1995. Public Space, Cambridge University Press.

Farid, 2012. Pola pemanfaatan koridor jalan kampung kauman kota malang sebagai ruang publik. Tesis Program Pasca Sarjana Universitas Brawijaya, Malang. Hall, ET. 1996. The Hidden Dimension. NY. Doubleday \& Company, Inc. Haryadi \& Setiawan B. 1995. Arsitektur Lingkungan dan Perilaku. Yogyakarta: PPPSL Kartono, JL. 2005. Konsep Ruang Tradisional Jawa Dalam Konteks Budaya. Dimensi Interior, Vol. 3, No. 2 Desember 2005: 124-136

Rapoport, A. 1977. Human Aspect of urban Form. Oxford: Pergamon. Snyder, C. James. 1985. Pengantar Arsitektur. Penerbit Erlangga Van de Ven, C. 1995. Ruang dalam Arsitektur. Jakarta: PT Gramedia Pustaka. 